\title{
FEATURES OF THE DEVELOPMENT OF MEDIA EDUCATION IN THE UNITED STATES OF AMERICA
}

\author{
Nataliia Prykhodkina \\ $\mathrm{PhD}$ in Education, Senior Lecturer at the Department of Pedagogy, \\ Administration and Social Work, State Higher Educational Institution \\ "University of Educational Management", Ukraine \\ e-mail: prykho2@gmail.com,orcid.org/0000-0002-6211-5546
}

\section{Summary}

In the article the author analyzed the features of the development of media education in the United States of America. Media education in the USA has come a long way in its development: from film experiments to the founding of the National Association for Media Literacy Education. There are presented content and the list of documents which regulate the development of media education, associations and organizations for media education in the USA. Abilities and skills which children should have for using media are defined. Statistics of Pew Research Center about time which children spend with media is given. The author analyzed concepts "media education" and "media literacy". The article examines several examples of using media educational tasks on different lessons. According to the documents of National Association for Media Literacy Education (NAMLE) principals and aims of media education are defined. The prospects for the development of this problem are shown.

Keywords: media, media literacy, principles of media education, association for media literacy, USA.

\section{DOI: https://doi.org/10.23856/3825}

\section{Introduction}

The intensive development of mass media (television, press, radio) and their growing influence on the younger generation require targeted preparation of the individual for the competent usage of media technologies. According to the Pew Research Center, 99\% of American families with children under 18 years of age have a TV. 74\% of families have cable or satellite TV, $69 \%$ have personal computers (and $85 \%$ of those are connected to the Internet). An American teenager spends more than 6 hours a day interacting with media technologies, $42 \%$ of this time children spend watching TV shows and films, and only $12 \%$ of it reading printed texts (Pew Research Center's Internet \& American Life Project, 2011). These alarming statistics are proving that a modern child should be guided in a growing informational environment and must have practical skills in working with media technologies. This is also evidenced by media education associations and numerous international conferences, such as: the Grunwald Declaration on Media Education (1982), UNESCO General Conference resolution (1989) which included "the development of critical media education", Vienna Conference "Education for the Media and the Digital Age" (1999), Seville Conference "Youth Media Education" (2002), Resolution of the European Parliament on media literacy in the world of digital technology (2008) (Motion for A European Parliament Resolution, 2008), the European Commission's Communication "A European approach to media literacy in the digital environment" (2007) (A European Approach to Media Literacy, 2007), where scientists and educators from many countries discuss the problems and trends in the development of media education. Today, the UNESCO, 
as international organization, emphasizes that media education is the priority in the development of pedagogy, defines it as part of the fundamental right of every citizen of any country to freedom of expression and information, and recommends including it in the national curricula of all states and in the system of additional and non-formal education (G. Onkovych, 2010). Therefore, the development of media education among the younger generation is an urgent pedagogical problem. Taking into account, that today the USA is one of the world's leaders in the field of media education, we consider reviewing and analyzing its history and experience in this field is to be appropriate. In our opinion, this will contribute to the development of media education in Ukraine as to a more effective process.

The purpose of our article is to review and analyze the main stages and directions of development of media education in the USA.

\section{Terminology analysis}

The concept of media education is relatively new. For the first time this term was used in documents of a joint meeting of the UNESCO Communication and Information Sector and the International Council on Film, Television (at present, the International Council on Film, Television and Audiovisual Communication (ICFT)) in 1973. The Oxford Encyclopedia (2001) defines media education as "media study". In English-speaking countries, the term "media education" is replaced by the synonym "media literacy". Because of that there is no single terminology for the definition of these concepts in pedagogical science, and scientists offer various options for formulating this concept. Here is the definition of media education presented in UNESCO documents - "it is teaching theory and practical skills with the aim of mastering modern media of communication, which are considered as part of a specific and autonomous field in pedagogical theory and practice, which should be distinguished from the use of media as auxiliary tools in teaching other sectors of knowledge, such as, for example, mathematics, physics or geography" (Kubey, R. \& Baker, F., 2000: 8).

The American researcher D. Considine notes that today in the USA both terms are used almost equally, where media education is knowledge about media, and media literacy is focused on the formation of critical thinking among young people and protection from the negative effects of media (D. Considine, 1999). But most of the world's scientists, for example, such as L. Masterman and K. Vorsnop, are inclined to believe that media education is a broader and more comprehensive concept than media literacy. K. Vorsnop also notes that media literacy is the result of media education, the study of media. The more you study media (using media), the more media literate you are, i.e. media literacy is the ability to experiment with, interpret, analyze and create media texts. R. Kubey believes that media literacy is the ability to use, analyze, evaluate and transmit messages in various forms (W. Costanzo, 1992). Based on the foregoing, we can conclude that all scientists are inclined to believe that media literacy is the media analysis and evaluation skills acquired during training.

\section{Stages of the development of media education}

Three main stages can be distinguished in the historical development of media education in the United States,: Stage I - the stage of the initial development of media education ( $60 \mathrm{~s}-70 \mathrm{~s}$ of the 20 th century), Stage II - the formation of the basic models of media education ( 80 s of the 20 th century), Stage III - the development of modern multimedia media education (90s of the 20th century) (J. Sim, 1977). 
The history of media education in the USA goes back for many decades. It began to emerge on the basis of cinematography forming, back in the 20 s of the 20 th century. Those were single practical courses embedded in school curricula, first based on the cinema art material, and subsequently on the materials of the press, radio and television. Until the end of the 50s of the 20 th century in the USA there was no holistic concept and system of media education. The first curriculum on media education was developed by the Canadian scientist Marshall McLuhan, which later influenced the development of American media education (K. Tyner, 1999).

So, in the early 60 s of the 20 th century US media education has focused on film education. Schoolchildren learned to film short documentary or role playing stories. It was during this period in the United States that the first Association for Screen Education emerged. However, in most cases, screen media education was practical. Pupils mastered the skills of using cinema and television equipment, and media materials were used to illustrate actual problems of society. It should be noted that during this period the development of aesthetic (artistic) media education begins. In some schools, the study introduced cinema language, the history of cinema, the work of famous screen workers, the aesthetics of films and a detailed analysis of media texts to interest students in art house masterpieces. Children studied some cinematic terminology and used it to analyze films viewed in the classroom. They analyzed the characters, plots, and means of creating the atmosphere of the film. Such viewings were constructed by analogy with the history of literature courses. But the artistic media education of the United States in this period coexisted in parallel with the so-called "injection" or "vaccination", which began to emerge in the 30 s and 40 s of the 20 th century Teachers were worried that the media could negatively affect children, form unacceptable values and norms of behavior, for example, students can get involved in violence on the television screen. Therefore, media education was aimed at protecting students from the negative impact of media on the moral and behavior of the younger generation (O. Fedorov, 2007).

In the 1970 s of the 20 th century television has become increasingly popular. As a result, educators began to realize the need for including film and television into the curriculum as separate subjects. Media education has also focused on the study of advertising, news and the influence of the media. At this time, approximately $35 \%$ to $40 \%$ of the total number of secondary schools offered students modules or courses called "Media" or "Mass Communication" (K. Tyner, 1999). These courses have focused on the study of television.

In 1969, educators at universities in Ohio and Utah prepared materials for the development of critical viewing. In 1973, with the support of a charitable American organization (Ford Foundation), a "critical viewing" movement appeared in the United States. The American Philosophical Association (APA) gives the following definition of the term "critical vision": "focused, self-regulatory judgment that ends with interpretation, analysis, assessment and interactivity, as well as an explanation of the obvious, conceptual, methodological, contextual considerations on which this judgment is based". American educators and researchers supported a political debate on televiolence and its impact on children. As a result, the mandatory "critical viewing" course has been introduced into the US education system. But soon this course was excluded from the curriculum (J. Sim, 1977).

In the $80 \mathrm{~s}$ Media education has begun to gain popularity among school teachers, teacher trade unions, professionals in the media industry and non-profit organizations. In different states pedagogical associations were created, which included the study of various aspects of media into educational programs. For example, the National Telemedia Council, a nonprofit educational organization, conducted various media educational symposia for teachers, parents, and researchers from different states. The Houston organization "The Southwest Alternate Media 
Project" hosted seminars, presentations, and further training education courses. On the initiative of teachers the number of electives for media education has increased significantly. Some teachers have tried to include media education in their humanitarian courses, technology programs, or even into a daily schedule. In some cases, a media education course has been added to the existing schedule as an optional subject, for example in Texas. So, during this period, supporters of media education tried to incorporate it into the school curriculum (R. Kubey \& F. Baker, 2000).

An important factor in the development of American media education was the development of extracurricular education. The extracurricular education was focused on the organization of educational TV programs, media programs in art galleries and museums, numerous children's exhibitions and film and television festivals. Such informal extracurricular courses in media education were common in almost all states of the country (W. Costanzo, 1999).

Many non-profit organizations contributed to the development of media education in the United States. But in general, most of them tried to adapt it to achieve social benefits. For example, media education acted as a promotion of a healthy lifestyle, the fight against violence and censorship on television. The result of such one-sided usage was that media information has practically turned into a form of political and social propaganda (O. Fedorov, 2007).

However, according to modern historians of pedagogy, media education in the United States during the 20th century did not develop very intensively, unlike in Great Britain, Canada, and Australia. One of the obstacles to its development was the American decentralized education system, where each state has its own independent policy in the field of secondary and higher education. And each educational institution develops its own autonomous curricula and yearly plans. At the same time, a number of media educational organizations (the National Council on Television and Media, the Center for Media Literacy and the Center for Media Education) created in the USA were not officially included in the state educational system and developed on their own initiative. Another limiting factor was the lack of training standards and a scientific data base for media education. Teachers could include various aspects of media education in their curriculum. The result of such situation in the United States is that, even today, various directions of media education are competing with each other. Some scholars believe that media education should focus on the analysis of media and focus on issues of power and ideology. Representatives of another direction prefer focusing on the ability to use the latest technologies and aim at mastering the skills necessary for the effective use of media technologies (R. Kubey, 1998).

Positive changes in the development of media education were identified only in the early 1990s, when US teachers and researchers began to turn to foreign experience. It was then that a variety of media began to play a dominant role in the life of the population. The state could no longer ignore the need to develop media education. It was during this period that it began to be regulated by state curricula. In April 1994, the US president signed into law Goals 2000: Educate America Act (P.L. 103-227). This law introduced educational standards in nine subjects, and the compulsory module on media education was included in the "Arts" discipline (Goals, 2000).

Media education began to develop rapidly. In 1992, Harvard University founded the first American Pedagogical Institute for Media Education. In 1993, after the national conference on media education, the Northwest Media Literacy Center was founded in Seattle (W. Costanzo, 1992).

By the mid-1990s educational institutions in 12 states (California, New York, Minneapolis, New Mexico, Texas, North Carolina, Wisconsin, Minnesota, etc.) have included 
compulsory media education modules in their programs. Five years later, 48 states, except Kansas and Kentucky, had courses in media education in their curricula $(R$. Kubey \& $F$. Baker, 2000). In 46 states, it was taught as part of the English language and the arts; in 30 states it was included in the curriculum in social sciences, history, law, ecology and medicine. It is also worth noting that at this stage of development, media education continued to be a teaching strategy that was used as propaganda of antisocial phenomena (fighting against smoking, alcoholism, drug addiction, violence, etc.) and as a continuation of the "injection" model against the negative effects of media (O. Fedorov, 2010). UNESCO supported this movement by creating the UNESCO International Clearinghouse on Children and Violence on the Screen. This organization collaborated with many media teachers of the world and was engaged in conducting scientific and pedagogical conferences, creating Internet sites, publishing books and magazines on the problem of the negative impact of media on children. In 2002, this organization received another name: The UNESCO International Clearinghouse on Children, Youth and Media. This change caused the organization to realize that the fight against televiolence is not the only task of media education. A more important area is the formation of critical, independent, creative thinking in the younger generation (O. Fedorov, 2010).

\section{The Role of Associations and National Organizations in the Development of Media Education in the USA}

Today, in the USA, media education is a priority in the development of education. There is a whole network of major media education associations: Center for Media Education in Washington, Center for Media Literacy in Los Angeles, Citizens for Media Literacy in North Carolina, Media Education Center in New Mexico, Educational Video Center in New York, Strategies for Media Literacy Association, National Alliance for Media Arts and Culture in San Francisco, Media Education Foundation, National Telemedia Council in Virginia, Media Arts Center in Seattle, etc. (W. Costanzo, 1992). A large number of conferences, Internet sites, publications, which today actively influence the development of media education in other countries, is the evidence of their active work.

In 2007, the International Technology Education Association, founded by NASA in collaboration with the US Department of Education, developed the National Standards for Educational Technology for Students, according to which, "students must be able to use the full range of digital media to find, organize, analyze and evaluate information from various sources". In 2009, the National Association for Media Literacy Education (NAMLE) developed a document on educational policy: The Core Principles of Media Literacy Education in the USA. This document defines the goal of media education as helping "individuals of any age to develop the skills of analysis and mastery of media necessary for critical thinking and effective communication in the modern world" (V. Ivanov, O. Volosheniuk, L. Kulchynska, 2011: 45). According to these documents, media education in the USA:

1) requires an active analytical and critical approach to the messages that we receive and create;

2) extends the concept of literacy into all types of media (including print);

3 ) is aimed to shape appropriate skills in individuals of any age;

4) aspires to educate well-informed, critical and active citizens who are the foundation of a democratic society;

5) is based on viewing the media as part of culture and an important agent of socialization; 
6) notes that people use their individual skills, beliefs and experience in order to construct their own meanings of media messages (V. Ivanov, O. Volosheniuk, L. Kulchynska, 2011).

The members of this association have developed "Five key questions that we should be guided by when analyzing media communications": who created the message? What techniques are used to attract my attention? What values, lifestyles and perspectives are presented in the message? Why was this message sent? How can other people understand this message differently from me? (V. Ivanov, O. Volosheniuk, L. Kulchynska, 2011). The developers (NAMLE) believe that these questions create a kind of analytical model that leads students to a deeper and more critical understanding of media messages.

\section{Integrating Media Education in School Subjects in the USA}

Today, media education is integrated into the discipline "Arts" in all fifty states. It aims "to implement visual skills and strategies for understanding and interpretation of visual media texts, and also on comprehension of the features and components of media texts of various spheres" (O. Fedorov, 2007: 83). For example, a media education course for high school students was developed at the University of Rhode Island. The goal of this course is to rear a competent media audience that will be able to distinguish lies from facts; audience that cannot be manipulated. To fulfill this task, students, along with teachers, watch various TV programs and commercials in the classroom, listen to the radio and read newspapers and magazines. Students learn to identify gender, ethnic, social, media stereotypes, analyze advertising, news, popular songs, television shows, and press materials by using this technique. Another example of this methodological approach is the introduction of media education in primary schools in Maryland. During the lessons, children also watch various videos, for example, a story about hamburgers: why are hamburgers not always as attractive and mouth-watering as in advertising? Such a plot demonstrates a bun, which is decorated with sesame seeds using tweezers before it has been filmed for advertisement so that it has a salable appearance. The result of this method is the development of independent critical thinking in children.

\section{Conclusions and suggestions}

According to the analysis of the scientific literature, we came to the conclusion that media education in the USA has come a long way in its development: from film experiments to the founding of the National Association for Media Literacy Education. Having originated in the mainstream of film education back in the 1920 s, for several decades it existed in the form of separate branches of the television, the press and radio material. Only in the early 60s media education began to gain popularity due to the rapid development of television. This period is characterized by the emergence of artistic media education, which coexisted with the so-called "injection", which aimed at overcoming the pathogenic influence of media on young people. The next decade was marked by the emergence of the "critical viewing" movement and the first media centers, conferences and the active work of teachers on integrating media education into school subjects. During this period, media education was not included in the state curriculum, but developed only via the initiative of teachers and non-profit organizations. Only in the early 90's media education began to be regulated by state educational standards. At present, school media education in the United States is at a fairly high level and is officially integrated into the curricula.

The prospects for the further development of this problem are: a detailed study of models and approaches of media education and trends in its development in the United States. 


\section{References}

Ivanov, V., Volosheniuk, O., Kulchynska, L. (2011). Mediaosvita ta mediahramotnist: korotkyi ohliad [Media education and media literacy: a review]. Kyiv: AUP. [in Ukrainian]

Onkovych, H. V. (2010). Mediaosvita v Ukraini: suchasnyi stan i perspektyvy rozvytku [Media education in Ukraine: current state and prospects of development]. Novi tekhnolohii navchannia, 62, 89-92. [in Ukrainian]

Fedorov, A. V., Novikova, A. A., Kolisnichenko, V. L. \& Karuna, I. A. (2007). Mediaobrazovanie v SSHA, Kanade i Velikobritanii [Media education in the USA, Canada and the UK]. Taganrog: Izd-vo Kuchma. [in Russian]

A European Approach to Media Literacy in the Digital Environment (2010). Retrieved from https://www.cedefop.europa.eu/en/news-and-press/news/european-approach-media-literacy-digital-environment [in English]

Considine, D. (1999). Media Education in United States of America. In: Educating for the media and the digital age. Vienna: Austrian Federal Ministry of Education and Cultural Affairs \& UNESCO (125-128). [in English]

Costanzo, W. (1992). Reading the Movie. Urbana, Illinois: National Council of Teachers of English. [in English]

Goals 2000: Educate America Act (2010). Retrieved from https://www2.ed.gov/legislation/ GOALS2000/TheAct/index.html [in English]

Kubey, R. (1998). Obstacles to the Development of Media Education in the United States. Journal of Communication (Winter), 48, 58-69. [in English]

Kubey, R. \& Baker, F. (2000). Has Media Literacy Found a Curricular Foothold? Telemedium. The Journal of Media Literacy, 46, 8-9. [in English]

Motion for A European Parliament Resolution on Media Literacy in a Digital World (2008). Retrieved from https://www.europarl.europa.eu/sides/getDoc.do?pubRef=-//EP//TEXT+RE$P O R T+A 6-2008-0461+0+D O C+X M L+V 0 / / E N \# t i t l e 1$ [in English]

Pew Research Center's Internet \& American Life Project (2011). Retrieved from http://pewinternet.org/Reports/2011/Teensandsocialmedia.aspx. [in English]

Sim, J. (1977). Mass Media Education in the U.S.A. In: Media Studies in Education. Paris: UNESCO. 74-88. [in English]

Tyner, K. (1999). New Directions for Media Education in the United States. In: Educating for the Media and the Digital Age. Vienna: UNESCO (251-272). [in English] 